ISSN 1392-3196

Zemdirbyste-Agriculture, vol. 100, No. 1 (2013), p. 105-111

UDK 634.1.004.12 / DOI 10.13080/z-a.2013.100.014

\title{
Spectrophotometrically determined pigment contents of intact apple fruits and their relations with quality: a review
}

\author{
Nadja SADAR, Andreja URBANEK-KRAJNC, Tatjana UNUK \\ University of Maribor \\ Pivola 10, 2311 Hoče, Slovenia \\ E-mail:nadja_sadar@yahoo.com
}

\begin{abstract}
Consumer expectations of apple fruit quality have been steadily increasing over the last couple of decades. One of the main quality attributes affecting product price is colour, determined primarily by the relative amounts of pigments chlorophylls, carotenoids, and anthocyanins, which can be measured non-destructively by visible spectrophotometry.

This paper provides a brief overview of studies dealing with the optical pigment-determination of intact apple fruits in visible part of electromagnetic spectrum. Firstly ripening-associated pigment changes in apples as well as the basics of light interaction and measurements in turbid materials are explained. Subsequently the two most appropriate methods for pigment determination of intact apple fruit are presented along with examples. This is followed by a discussion of the various reflectance and remittance indices for the qualification, as well as quantification, of the main apple pigments. Results are reported regarding studies on the relationships between spectral data and derived indices with various destructive quality and ripening parameters. In the conclusion some of the main findings reviewed in this paper are outlined and discussed briefly.
\end{abstract}

Key words: anthocyanins, apple, chlorophylls, colour, maturity, quality, visible spectrophotometry.

\section{Introduction}

Consumer expectations of quality, defined as all those characteristics of the product leading to their satisfaction, have been steadily increasing over the last couple of decades. One of the main quality attributes affecting apple fruit acceptance and price is colour (Abbott, 1999; Kays, 1999), determined primarily by the relative amounts of pigments which undergo remarkable ripening transformations (Knee, 1972; Merzlyak et al., 2003). During ripening, the fully functional photosynthetic apparatus of the apple fruit (Blanke, Lenz, 1989) disassembles, which involves chloro-tochromoplast conversions, resulting in a gradual decline of chlorophylls content accompanied by the retention, as well as accumulation, of significant amounts of carotenoids (Knee, 1972; Merzlyak et al., 2003; Solovchenko et al., 2010) that is reflected in a brightening of the background colour. Red cultivars are additionally characterized by the accumulation of large amounts of vacuolar pigments anthocyanins (Abbott, 1999) responsible for the development of blush colour, which has a profound influence on the consumer's choice of purchase due to a commonly held belief of positive correlations between a red colour and taste (Kays, 1999).

Because of the aforementioned ripening changes and their impact on fruit quality, the amounts of pigments, as well as their relative proportions, are important indices of physiological characteristics of fruit, and have thus been considered for the optimal harvest window, as well as quality estimation (Abbott, 1999; Zude-Sasse et al., 2002; Herold et al., 2005; Solovchenko et al., 2005;
2010; Zude et al., 2006; Geyer et al., 2007). In order for the knowledge of the existing relations between pigments and physiological processes occurring in fruits to be transferred into practice, nondestructive methods needed to be developed (Chen, Nattuvetty, 1980; Merzlyak et al., 2003; Herold et al., 2005; Zude et al., 2006). These alternatives to expensive and time consuming chemical determination of pigments enable continous monitoring of individual fruit development thus facilitating data interpretation by avoiding the stochastic variability of heterogeneous fruit (Herold et al., 2005).

\section{Pigment and colour analysis of intact fruits}

In optically dense or turbid materials, such as fruits, only about $4 \%$ of incident light is reflected from the surface as regular reflection providing gloss. The remaining $96 \%$ of radiation is transmitted through the surface into cellular structures where after interactions with different molecules and atoms, photons of specific wavelength are absorbed according to their energy levels (Butz et al., 2005; Zude et al., 2007). The rest of the light is scattered in all directions, eventually radiating from the surface in the vicinity (body reflectance) or some distance away from the incident light where it is recorded by a light detector. Radiation leaving the sample has characteristics dependend on the properties of the product and the incident light; therefore determining the optical characteristics of output light provides valuable 
information about related quality factors. Within visible spectra of electromagnetic radiation, the principle absorbing molecules are pigments such as chlorophylls, carotenoids, and anthocyanins (Abbott, 1999; Merzlyak et al., 2003; Butz et al., 2005). Their accumulation is reflected in the spectra as peak widening thus enabling not only qualitative but also quantitative determination of individual pigments (Zude et al., 2007).

Three different modes of sample measurements are suggested for analysis of colour and other quality parameters of intact fruits (Herold et al., 2009).

In the transmittance mode the light sourcesample-detector is aligned at $180^{\circ}$. The detector measures the amount of light transmitted through the total volume of tissue within the path of the measuring radiation. The main disadvantages of this method are the need for high light intensities and relatively small amounts of incident light actually reaching the detector (Herold et al., 2009). Nevertheless this technique has been successfully developed for determining pigment contents of intact apples, as well as their maturity and quality.

In a reflectance mode fieldview of light detector only includes the directly illuminated area of the sample and records the light reflected from a few millimetres under the surface. Both the absorption and the scattering properties are responsible for the variation of measured spectra, therefore Beer's Law, which is valid only for transparent homogenous material, should be replaced by the Kubelka-Munk theory (Herold et al., 2009):

$\mathrm{R}=\mathrm{F}(\mathrm{R})=(1-\mathrm{R})^{2} / 2 \mathrm{R}=\mathrm{k} / \mathrm{s}=\mathrm{Ac} / \mathrm{s}$,

where $\mathrm{R}$ is reflectance from sample with infinite thickness, $\mathrm{k}$ - absorption coefficient, $\mathrm{s}$ - scattering coefficient, c - concentration of the absorbing species, A - absorbance.

As it uses diffuse instead of directional light for illumination, D/8 geometry is preferred over $45 / 0$ geometry for measurements of intact fruits (Herold et al., 2009). The recorded radiation of integrated sphere reflectance mainly consists of specular reflection providing gloss and, to a lesser extent radiation that interacts with the sample (diffuse reflectance), thus making it very susceptible to surface as well as environmental changes. This method has been successfully employed for determining pigment changes in apple fruit during development and under stress conditions (Merzlyak et al., 2002; 2003; Solovchenko et al., 2005; 2010) as well as for apple maturity (Solovchenko et al., 2005; Tijskens et al., 2009) and quality estimation (Unuk et al., 2008; 2012). Recently, reflectance technology combined with novel process-oriented modelling has been used to determine the effects of biological variance on the colour development of different produce (Tijskens, Konopacki, 2003; Tijskens et al., 2003; 2009; 2011; Unuk et al., 2008).

Interactance mode is a compromise between transmission and reflectance modes in every one of its characteristics. The light source sample-detector angle is less than $180^{\circ}$ and the detector is shielded from specular reflection, hence receives only light remitted from within the sample. Effective pathlength of light transmission (i.e. depth of light penetration) into the fruit approximately equals the distance between the illuminator and the detector (Chen, Nattuvetty, 1980) so when measuring the pigment contents of intact apple fruits, the distance between them needs only be a few millimetres. This method has been successfully applied for measurements of different quality and maturity attributes in various products (Zude-Sasse et al., 2002; Herold et al., 2005; Geyer et al., 2007; Zude et al., 2007; Herold et al., 2009).
In apple fruits, pigments are concentrated in the epidermis and associated tissues above parenchyma with strong light scattering properties (Butler, Norris, 1960; Solovchenko et al., 2010), therefore reflectance and interactance seem to be the most useful modes of sample measurement in order to evaluate their pigment contents (Herold et al., 2009).

Development of optical techniques for determining the pigments of intact fruits for practical applications, assumes the spectral properties of pigments are species- and variety-independent and remain unchanged during ripening, however this is not the case (Merzlyak etal., 2003; Herold etal., 2005). The assessment of pigments in intact apple fruits is further complicated by considerable overlapping of absorption between different pigments (Merzlyak et al., 2003; Merzlyak, 2006; Zude et al., 2007), as well as by the non-linear relationships of pigment content vs. reflectance (Merzlyak et al., 2003; Solovchenko et al., 2010) or transmittance (Herold et al., 2009), and considerable differences among scattering characteristics of apple tissues (Zude et al., 2007).

\section{Spectral signature and indices of apple fruit}

Apple ripening is accompanied by characteristic changes in spectral recordings within visible spectra. With progressive maturity, magnitude of the chlorophyll absorption peak of near $680 \mathrm{~nm}$ decreases and simultaneous backward shift of the red edge, designated as the inflection point at the long-wave flank of chlorophyll absorption, towards shorter, red wavelenghts of the spectrum occurs (McGlone et al., 2002; Zude-Sasse et al., 2002; Herold et al., 2005). On the other hand, the intensity of an anthocyanin absorbance-peak of near $550 \mathrm{~nm}$ increases, which is reflected in the spectra as decreasing reflectance or transmittance of between 675 (570) and 500 (400) nm, as well as a displacement of the green-edge towards longer wavelengths (Herold et al., 2005). In anthocyanin-free fruit there is retention of low reflectance in the blue region of the spectra between $400-520 \mathrm{~nm}$, where reflectance is governed by the combined absorption of chlorophylls and carotenoids (Solovchenko et al., 2010).

Width at half height of the absorbance peak is an excellent indicator of pigment quantity. Alternatively, indices composed of spectral bands showing maximal sensitivity to the pigment in question, can be calculated from raw spectral data (Merzlyak et al., 2003; Herold et al., 2009). The measurement criteria for establishing quality indices fall into four groups: 1) single-wavelength measurements; 2) difference-measurements - changes in the optical measurement at two $\lambda$, indicating average slope in an area between these two $\lambda ; 3$ ) ratio at two $\lambda$, example: $\mathrm{I}_{698} / \mathrm{I}_{760}$ (Zude, 2003) or $\mathrm{R}_{675} / \mathrm{R}_{760}$ (Marquina et al., 2004) for chlorophylls estimation; 4) any combination of the above, example: $\mathrm{R}_{800} / \mathrm{R}_{550}-\mathrm{R}_{80} / \mathrm{R}_{700}$ for anthocyanin estimation, according to Merzlyak et al. (2003).

A conceptual semi-analytical three-band model linking the reciprocal reflectance of apple fruit with its pigment content was proposed for reflectance measurements in the form: $\mathrm{P}=\left(\mathrm{R}_{\lambda 1}{ }^{-1}-\mathrm{R}_{\lambda 2}{ }^{-1}\right) \times \mathrm{R}_{\lambda 3}$. This model includes reflectance in three wavelength bands $\left(\lambda_{1}\right.$, $\left.\lambda_{2}, \lambda_{3}\right)$. Reflectance in the spectral band $\lambda_{1}$ is maximallysensitive to the pigment of interest but is also affected by other pigments and scattering properties of the fruit. Reflectance at $\lambda_{2}$ eliminates the effects of other pigments and is minimally-dependent on the studied pigment of 
interest, whilst reflectance at $\lambda_{3}$ is governed mainly by scattering properties and is therefore (in the case of apple fruits) always measured at $800 \mathrm{~nm}$ (Solovchenko et al., 2010). Either reflectance at $640 \mathrm{~nm}$ or at $700 \mathrm{~nm}$ is employed as the reflectance band of maximal sensitivity $\left(\lambda_{1}\right)$ because chlorophylls absorbs in the red as well as in the green part of the spectra. Thus two algorithms, showing high linear correlations with chlorophyll in different apple varieties were proposed in the forms $\mathrm{CI}_{1}$ $=\left(\mathrm{R}_{700}{ }^{-1}-\mathrm{R}_{800}{ }^{-1}\right) \times \mathrm{R}_{800}$ and $\mathrm{CI}_{2}=\left(\mathrm{R}_{640}{ }^{-1}-\mathrm{R}_{800}{ }^{-1}\right) \times \mathrm{R}_{800}$ (Merzlyak et al., 2003). Absorption in the green region of the spectra is governed by combined absorption of chlorophylls and anthocyanins $\left(\lambda_{1}\right)$ so when assessing anthocyanin content, it is necessary to eliminate the significant effect of chlorophylls, therefore the reflectance for $\lambda_{2}$ is measured at $700 \mathrm{~nm}$, where chlorophylls are the sole absorber (Merzlyak et al., 2003). The anthocyanin reflectance index was suggested in the form of ARI = $\left(\mathrm{R}_{550}{ }^{-1}-\mathrm{R}_{700}{ }^{-1}\right) \times \mathrm{R}_{800}$. Elimination of the chlorophylls effects (either in the red or in the green parts of the spectrum) on reflectance spectra is also necessary for the determination of carotenoids which exhibit maximum absorbance near $520 \mathrm{~nm}\left(\lambda_{1}\right)$. Two algorithms were proposed CRI $=\left(\mathrm{R}_{520}{ }^{-1}-\mathrm{R}_{700}{ }^{-1}\right) \times \mathrm{R}_{800}, \mathrm{CRI}_{2}=\left(\mathrm{R}_{520}{ }^{-1}-\right.$ $\left.\mathrm{R}_{550}{ }^{-1}\right) \times \mathrm{R}_{800}$. Both correlate linearly to carotenoid content, though they are inapplicable to anthocyanin containing fruit (Solovchenko et al., 2010). All these algorithms, devised from semi analytical 3 band model, sufficiently correlate with the pigments of interest and are insensitive to the anatomical and morphological characteristics. They could therefore be applied to unrelated data (Merzlyak et al., 2003), though assessing carotenoid contents in red varieties using this approach is, as yet, impossible (Merzlyak et al., 2005).

Besides the abovementioned reflectance indices, indexes have also been suggested in the forms of $\mathrm{I}_{\mathrm{A}}=\left(\mathrm{R}_{800} / \mathrm{R}_{500}-\mathrm{R}_{800} / \mathrm{R}_{700}\right)$ (Merzlyak et al., 2003), $\operatorname{IanI}=\left(\mathrm{I}_{630}-\mathrm{I}_{570}\right) /\left(\mathrm{I}_{630}+\mathrm{I}_{570}\right)$ (Herold et al., 2009), NBI $=\left(\mathrm{R}_{630}-\mathrm{R}_{750}\right) /\left(\mathrm{R}_{630}+\mathrm{R}_{750}\right)$ (Geyer et al., 2007) and $\mathrm{I}_{\mathrm{NA}}=\left(\mathrm{R}_{760}{ }^{750} \mathrm{R}_{570}\right) \stackrel{630}{ }\left(\mathrm{R}_{760}+\mathrm{R}_{570}\right)$ (Herold et al., 2005) for estimating anthocyanin content, whilst indices for chlorophylls determination include, but are not limited to, the red edge index designated as the inflection point at the longwave-flank of chlorophylls absorption (Herold et al., 2009), remittance indexes of chlorophyll decrease IchlD $=\left(\mathrm{I}_{750}-\mathrm{I}_{700}\right) /\left(\mathrm{I}_{750}+\mathrm{I}_{700}\right)$, as well as Inchl $=\left(\mathrm{R}_{760}\right.$ $\left.-\mathrm{R}_{695}\right) /\left(\mathrm{R}_{760}+\mathrm{R}_{695}\right)$ (Herold et al., 2005; Geyer et al., $2007)$, and reflectance indices $I_{c h l}=\left(R_{800} / R_{700}-1\right), R_{800} /$ $\mathrm{R}_{700}$ and $\mathrm{R}_{800} / \mathrm{R}_{640}$ (Merzlyak et al., 2003). Some of the proposed indices are presented in Table 1.

Table 1. Brief overview of some spectral indices for pigment analysis

\begin{tabular}{|c|c|c|c|c|c|}
\hline Cultivar & $\begin{array}{c}\text { Acquisition } \\
\text { mode }\end{array}$ & Spectral index & $\begin{array}{c}\text { Measured } \\
\text { pigment }\end{array}$ & Correlation & Reference \\
\hline various & interactance & OD (740-695) nm & chlorophylls & $\mathrm{R}=0.96$ & Yeatman, Norris, 1965 \\
\hline 'Idared' & & & & $\mathrm{R}=0.65$ & \\
\hline $\begin{array}{l}\text { 'Golden Delicious' } \\
\text { 'Elstar' } \\
\text { 'Jonagold' }\end{array}$ & interactance & red edge & chlorophylls & $\begin{array}{l}\mathrm{R}=0.80 \\
\mathrm{R}=0.57 \\
\mathrm{R}=0.82\end{array}$ & Zude-Sasse et al., 2002 \\
\hline $\begin{array}{l}\text { 'Boskoop' } \\
\text { 'Jonagold' } \\
\text { 'Elstar' } \\
\end{array}$ & interactance & red edge & chlorophylls & $\begin{array}{l}\mathrm{R}=0.98 \\
\mathrm{R}=0.97 \\
\mathrm{R}=0.99\end{array}$ & Zude, Herold, 2002 \\
\hline various & reflectance & 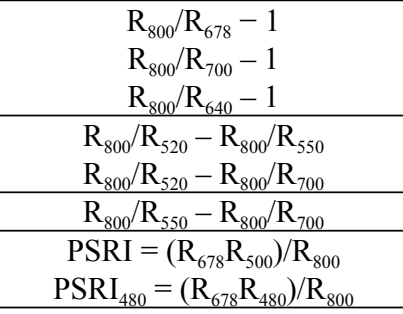 & $\begin{array}{l}\text { carotenoids } \\
\text { anthocyanins } \\
\begin{array}{l}\text { carotenoids/ } \\
\text { chlorophylls }\end{array}\end{array}$ & $\begin{array}{l}\mathrm{R}=0.92 \\
\mathrm{R}=0.94 \\
\mathrm{R}=0.93 \\
\mathrm{R}=0.83 \\
\mathrm{R}=0.80 \\
\mathrm{R}>0.93 \\
\mathrm{R}=0.88 \\
\mathrm{R}=0.94 \\
\end{array}$ & Merzlyak et al., 2003 \\
\hline 'Elstar' & interactance & $\begin{array}{c}\text { red edge } \\
\mathrm{I}_{698} / \mathrm{I}_{760} \\
\text { NDVI }=\left(\mathrm{I}_{750}-\mathrm{I}_{705}\right) /\left(\mathrm{I}_{750}+\mathrm{I}_{705}\right) \\
\end{array}$ & chlorophylls a & $\begin{array}{l}\mathrm{R}=0.753 \\
\mathrm{R}=0.814 \\
\mathrm{R}=0.837\end{array}$ & \multirow{2}{*}{ Zude, 2003} \\
\hline 'Jonagold' & interactance & $\begin{array}{c}\text { red edge } \\
\mathrm{I}_{698} / \mathrm{I}_{760} \\
\text { NDVI }=\left(\mathrm{I}_{750}-\mathrm{I}_{705}\right) /\left(\mathrm{I}_{750}+\mathrm{I}_{705}\right) \\
\end{array}$ & chlorophylls a & $\begin{array}{l}\mathrm{R}=0.703 \\
\mathrm{R}=0.885 \\
\mathrm{R}=0.827\end{array}$ & \\
\hline 'Golden Delicious' & interactance & $\begin{array}{c}\text { NDVI }=\left(\mathrm{I}_{780} \mathrm{I}_{660}\right) /\left(\mathrm{I}_{780}+\mathrm{I}_{660}\right) \\
\mathrm{NAI}=\left(\mathrm{I}_{780} \mathrm{I}_{570}\right) /\left(\mathrm{I}_{780}+\mathrm{I}_{570}\right)\end{array}$ & chlorophylls & $\begin{array}{l}\mathrm{R}=0.779 \\
\mathrm{R}=0.625\end{array}$ & Rutkowski et al., 2008 \\
\hline $\begin{array}{l}\text { 'Elstar' } \\
\text { 'Pinova' } \\
\text { 'Topaz' }\end{array}$ & interactance & $\mathrm{I}_{\mathrm{chlD}}=\left(\mathrm{I}_{750} \mathrm{I}_{700}\right) /\left(\mathrm{I}_{750}+\mathrm{I}_{700}\right)$ & chlorophylls & $\begin{array}{l}\mathrm{R}=0.92 \\
\mathrm{R}=0.87 \\
\mathrm{R}=0.92\end{array}$ & Herold et al., 2009 \\
\hline
\end{tabular}

OD - optical density, PSRI - plant senescence reflectance index, NDVI - normalized difference vegetation index, NAI - normalized anthocyanin index, $\mathrm{I}_{\text {chID }}$ - chlorophyll decrease index, I - interactance at subscribed wavelength, $\mathrm{R}$ - reflectance at subscribed wavelength

Zude (2003) obtained better harvest maturity predictions from remittance readings compared to reflectance readings. Because chosen wavelenghts for pigment estimations differ considerably between reflectance and remission indices, making transferability of results of different studies difficult. It has been suggested that a clear distinction ought to be made between those indices obtained by reflectance and the interactance technique (Herold et al., 2005). 


\section{Relations between spectral data and quality parameters}

Obtaining relationships between spectral data and standard parameters of quality or maturity is only possible to the extent to which those attributes relate to the pigment changes inherent in fruit reflectance or transmission spectra. It has been proven that chlorophyll is linked to quality indices such as soluble solid content and firmness, thus its content determined either destructively or nondestructively, was often used for quality evaluation and to predict the optimal harvest date of apples (Zude et al., 2006). In line with these findings, Peirs and co-workers (2001) obtained strong correlations between spectral data from the visible region and the total number of days before the picking date, which in turn correlated well with different quality and maturity indices, thus ensuring better predictions of optimal harvest dates compared to the Streif index (SI). Strong correlations were reported to exist between the peak absorbance of chlorophylls at $680 \mathrm{~nm}$ and the harvest date $(\mathrm{R}=0.59)$, background colour $(\mathrm{R}=0.74)$ and the starch index SI $(\mathrm{R}=0.64)$ whilst firmness (TMP) and soluble solids content (SSC) had somewhat weaker correlation coefficients of 0.48 and 0.46 , respectively (McGlone et al., 2002). Spectral data in the wavelength range, governed mainly by chlorophylls absorption were additionally found to be linked to sweetness and acidity (Watada et al., 1985), as well as with some textural attributes such as mealiness, crunchiness (Mehinagic et al., 2003), crispness, juiciness, and toughness (Watada et al., 1985). These findings only partially agree with those reported by Kuckenberg and his co-workers (2008) for 'Golden Delicious' and 'Jonagold' because even though chemically determined chlorophylls content was linked to titratable acids (TA) $(\mathrm{R}=0.52-0.57)$, SSC $(\mathrm{R}=0.45-0.46)$ and SI $(\mathrm{R}=0.51-0.76)$, the correlations acquired were considerably weaker compared to those obtained between chemically determined chlorophylls $(\mathrm{R}=0.65-0.77)$ as well as chlorophylls index NDVI $(\mathrm{R}=$ $0.70-0.71)$, and fruit firmness. In 'Golden Delicious', but not 'Jonagold', significant correlation was also observed between anthocyanin index NAI and firmness, which can be explained by taking into account strong correlations $(\mathrm{R}=0.91)$ found between NAI and chlorophylls content in 'Golden Delicious' whilst, mainly due to insignificant correlation obtained for the sun exposed part $(\mathrm{R}=0.11)$ of the fruit, a weaker one $(\mathrm{R}=0.46)$ was found in 'Jonagold'. The relationship between chlorophylls content and fruit firmness was further confirmed by Rutkowski and his colleagues (2008) who obtaining better predictions of chlorophylls content using the index of anthocyanin (NAI) than with NDVI, reported significantly high correlations $(\mathrm{R}=0.86)$ between fruit firmness and NAI. The latter was also found to correlate well $(\mathrm{R}=0.81)$ with TA (Rutkowski et al., 2008). As per Kuckenberg et al. (2008) NDVI of both 'Golden Delicious' $(\mathrm{R}=0.70)$ and 'Jonagold' $(\mathrm{R}=0.60)$ strongly correlate with the Streif index, whereas correlation coefficients between NAI and SI were 0.71 and 0.10 for 'Golden Delicious' and 'Jonagold', respectively. In contrast, only very weak correlations between both spectral indices and Streif index were reported for 'Golden Delicious' by Rutkowski et al. (2008), although NAI was strongly linked to fruit's physiological stages based on internal ethylene concentration (IEC). A possible reason for this inconsistency lies in the subjectivity of starch index estimations (Peirs et al., 2002), leading to inaccuracies of the calculated Streif index. This is additionally confirmed by weak correlations found between NAI and starch pattern index (Rutkowski et al., 2008). At first glance the results of these studies seem to contradict each other, since Rutkowski et al. (2008) claim that the most appropriate index for assessing apple fruit maturity is NAI, whereas Kuckenberg et al. (2008) believe NDVI is better suited for this purpose. Subsequent study has revealed that the usefulness of spectral indices for predicting maturity is variety-specific, as NAI was a better predictor of ripening in 'Golden Delicious', while in 'Goldeniszyk' better predictions were obtained by NDVI (Rutkowski et al., 2009). Upon further investigation, when considering the relationships between pigment contents and spectral indices it becomes clear that in all these studies maturity as well as quality indices were correlated mainly to chlorophylls content. However, chlorophylls content per se is not a reliable indicator of apple maturity (McGlone et al., 2002; Zude-Sasse et al., 2002). Instead, optically determined contents of both chlorophyll and carotenoid pigments were proposed and successfully employed for this purpose in 'Antonovka' apples (Solovchenko et al., 2005), whilst PSRI, which highly correlates with the chl/car ratio accurately predicts fruit maturity, but is inapplicable for anthocyanin containing apples (Merzlyak et al., 2003). A brief overview of the relationship between the spectral data of the visible spectra and different quality and maturity parameters is presented in Table 2. Continuous monitoring and evaluations of links amongst recorded spectral data and standard parameters of quality and maturity are fundamentally important when putting nondestructiveopticalmethodsintopractice. By enhancing physiological knowledge, the chances of both influencing as well as indirectly measuring such relationships greatly increase (Butz et al., 2005). Though pigments are known to correlate with the conventional parameters of maturity, correlations between the latter and spectral data are often insufficient for reliable assessment of quality attributes such as SSC, acidity, and fruit firmness (Zude et al., 2006). Different reasons as to why this phenomena occurs were given: the high heterogeneity of apple fruit, the subjectivity of starch index assessment (Peirs et al., 2002), the application of destructive methods, that inevitably lead to uncertainties caused by biological variability (Tijskens, Konopacki, 2003; Tijskens et al., 2003; 2009), weak correlations between pigments and spectral data due to co-pigmentation, differing scattering properties, absorption by other components of fruit (Herold et al., 2009), etc. Insufficiently high correlations can also result from interference of different environmental and production factors (Abbott, 1999) decoupling pigments changes from ethylene dependent ones (Blankenship, Dole, 2003). In particular, ignoring differing maturity stages between the shaded and sunlit sides of fruit leads to poor correlations between pigments and fruit firmness (Solovchenko et al., 2005; 2010; Kuckenberg et al., 2008). Additionally different cultivars might not exhibit the same behaviour under identical conditions (Herold et al., 2005; Kuckenberg et al., 2008).

In the light of the findings described in the previous paragraph, it is of paramount importance to know exactly what is being measured and to realize the limitations of indirect measurements (Abbott, 1999). 
Table 2. Brief overview of correlations between spectral data and certain apple quality parameters

\begin{tabular}{|c|c|c|c|c|c|}
\hline Cultivar & $\begin{array}{l}\text { Acquisition } \\
\text { mode }\end{array}$ & Spectral index & $\begin{array}{l}\text { Indicative } \\
\text { substance } \\
\text { measured }\end{array}$ & Correlation & Reference \\
\hline various & reflectance & $380-800 \mathrm{~nm}$ & chlorophylls & optimal picking date $(\mathrm{R}=0.85)$ & Peirs et al., 2001 \\
\hline $\begin{array}{l}\text { 'Royal } \\
\text { Gala' }\end{array}$ & interactance & $680 \mathrm{~nm}$ & chlorophylls & $\begin{array}{c}\text { harvest date }(\mathrm{R}=0.59) \\
\text { background colour }(\mathrm{R}=0.74) \\
\mathrm{SI}(\mathrm{R}=0.64) \\
\text { firmness }(\mathrm{R}=0.48) \\
\mathrm{SSC}(\mathrm{R}=0.46)\end{array}$ & $\begin{array}{l}\text { McGlone } \\
\text { et al., } 2002\end{array}$ \\
\hline \multirow{2}{*}{ 'Jonagold' } & \multirow{2}{*}{$\begin{array}{c}\text { Interactance } \\
\text { reflectance }\end{array}$} & \multirow{2}{*}{ red edge } & \multirow{2}{*}{ chlorophylls } & ripeness $(\mathrm{R}=0.94)$ & \multirow{2}{*}{$\begin{array}{l}\text { Zude-Sasse } \\
\text { et al., } 2002\end{array}$} \\
\hline & & & & $\mathrm{R}=0.89$ & \\
\hline \multirow{2}{*}{$\begin{array}{l}\text { 'Golden } \\
\text { Delicious' }\end{array}$} & \multirow{4}{*}{ interactance } & $\begin{array}{c}\mathrm{NDVI}=\left(\mathrm{R}_{780}-\mathrm{R}_{660}\right) / \\
\left(\mathrm{R}_{780}+\mathrm{R}_{669}\right)\end{array}$ & chlorophylls & $\begin{array}{c}\text { firmness }(\mathrm{R}=0.71) \\
\text { Streif index }(\mathrm{R}=0.70)\end{array}$ & \multirow{4}{*}{$\begin{array}{l}\text { Kuckenberg } \\
\text { et al., } 2008\end{array}$} \\
\hline & & $\begin{array}{c}\mathrm{NAI}=\left(\mathrm{R}_{780}-\mathrm{R}_{570}\right) / \\
\left(\mathrm{R}_{780}+\mathrm{R}_{570}\right)\end{array}$ & anthocyanins & $\begin{array}{c}\text { firmness }(\mathrm{R}=0.70) \\
\text { Streif index }(\mathrm{R}=0.71)\end{array}$ & \\
\hline \multirow{2}{*}{ 'Jonagold' } & & $\begin{array}{c}\mathrm{NDVI}=\left(\mathrm{R}_{780}-\mathrm{R}_{660}\right) / \\
\left(\mathrm{R}_{780}+\mathrm{R}_{669}\right)\end{array}$ & chlorophylls & $\begin{array}{c}\text { firmness }(\mathrm{R}=0.70) \\
\text { Streif index }(\mathrm{R}=0.60)\end{array}$ & \\
\hline & & $\begin{array}{c}\mathrm{NAI}=\left(\mathrm{R}_{780}-\mathrm{R}_{570}\right) / \\
\left(\mathrm{R}_{780}+\mathrm{R}_{570}\right)\end{array}$ & anthocyanins & Streif index $(\mathrm{R}=-0.10)$ & \\
\hline $\begin{array}{l}\text { 'Golden } \\
\text { Delicious' }\end{array}$ & interactance & $\mathrm{NAI}=\left(\mathrm{I}_{780} \mathrm{I}_{570}\right) /\left(\mathrm{I}_{780}+\mathrm{I}_{570}\right)$ & anthocyanins & $\begin{array}{c}\text { firmness }(\mathrm{R}=0.862) \\
\mathrm{TA}(\mathrm{R}=0.810)\end{array}$ & $\begin{array}{l}\text { Rutkowski } \\
\text { et al., } 2008\end{array}$ \\
\hline $\begin{array}{l}\text { 'Golden } \\
\text { Delicious' }\end{array}$ & reflectance & chromaticity values $\mathrm{L}, \mathrm{a}, \mathrm{b}$ & colour & $\begin{array}{c}\text { SSC with } \mathrm{L}^{*}(\mathrm{R}=0.38) \\
\text { SSC with } \mathrm{b}^{*}(\mathrm{R}=0.37) \\
\text { malic acid with } \mathrm{a}^{*}(\mathrm{R}=0.44)\end{array}$ & $\begin{array}{l}\text { Unuk } \\
\text { et al., } 2008\end{array}$ \\
\hline 'Elstar' & interactance & red edge & chlorophylls & harvest date $(\mathrm{R}=0.69)$ & $\begin{array}{l}\text { Herold } \\
\text { et al.,2009 }\end{array}$ \\
\hline $\begin{array}{l}\text { 'Antonovka } \\
\text { sunlit' }\end{array}$ & reflectance & $\mathrm{PSRI}_{480}=\left(\mathrm{R}_{678}-\mathrm{R}_{480}\right) / \mathrm{R}_{800}$ & $\begin{array}{l}\text { chlorophylls/ } \\
\text { carotenoids }\end{array}$ & IEC $(\mathrm{R}=0.67-0.69)$ & $\begin{array}{l}\text { Solovchenko } \\
\text { et al., } 2011\end{array}$ \\
\hline
\end{tabular}

SI - Streif index, SSC - soluble solids content, NDVI - normalized difference vegetation index, NAI - normalized anthocyanin index, TA - titratable acids; L, a, b - chromaticity parameters, PSRI - plant senescence reflectance index, IEC - internal ethylene content, I - interactance at subscribed wavelength, $\mathrm{R}$ - reflectance at subscribed wavelength

\section{Conclusions}

1. Recently, various nondestructive methods, including hyperspectral imaging, X-rays, impact and acoustics, electronic nose, and different optical methods have been developed for quality and ripeness evaluation of intact agricultural products (Abbott, 1999; Barcelon et al., 1999; Young et al., 1999; Zude et al., 2002; Butz et al., 2005). The latter include the spectroscopy in the visible region reviewed in this article.

2. Although the optical properties of intact apples are still somewhat unclear, considerable progress has been made in this area over the last couple of decades. It has been shown that spectroscopy in the visible range can be efficiently and reliably used for the identification and quantification of main apple-fruit pigments and, consequently for determination of its physiological state, quality and ripening rate (Knee et al., 1972; Watada et al., 1985; Zude et al., 2002; 2006; Merzlyak et al., 2003).

3 . However, the reported correlations between various quality attributes and spectral data reviewed in this article are often weak. One of the main reasons for inaccurate predictions of quality using spectral data lies in the fact that the mechanism for developing taste as one of the most important apple fruit quality components has not yet been fully defined on an individual level. Instead, only the mean values over several samples or batches of products have been used in the majority of studies, although the existence of high heterogeneity of apple fruit obscuring the occurring reactions and actual relations between different quality parameters as well as relations between various management practices and taste compounds has long been known. As a solution to this problem novel, process-oriented fundamental modelling, allowing the source of variation present in the product to be traced back to its growth conditions and thus possibly enabling improvements in production as well as storage practices, leading to the production of high quality fruit has been proposed by several scientists (De Ketelaere et al., 2006; Hertog, 2002; Tijskens, Konopacki, 2003; Tijskens et al., 2003).

4. Further investigations are required for the optimization of VIS methods for practical applications and once the relationships for different cultivars, geographical regions and different weather conditions are being accurately predicted, it is expected that technology, with its many advantages over standard destructive quality and maturity estimation methods, will become more widely used. The same can be said for other nondestructive techniques and in the future we expect more studies (like those from DiNatale et al., 2002) applying data fusion of different methods thus enabling better predictions of apple quality and maturity.

Received 14032012

Accepted 27092012

\section{References}

Abbot J. A. 1999. Quality measurement of fruits and vegetables. Postharvest Biology and Technology, 15 (3): 207-225 http://dx.doi.org/10.1016/S0925-5214(98)00086-6

Barcelon E. G., Tojo S., Watanabe K. 1999. Relating X-ray absorption and some quality characteristics of mango fruit (Mangifera indica L.). Journal of Agricultural and Food Chemistry, 47 (9): 3822-3825 http://dx.doi.org/10.1021/jf980690e

Blanke M. M., Lenz F. 1989. Fruit photosynthesis. Plant, Cell and Environment, 12 (1): 31-46 http://dx.doi.org/10.1111/j.1365-3040.1989.tb01914.x 
Blankenship S. M., Dole J. M. 2003. 1-methylcyclopropene: a review. Postharvest Biology and Technology, 28 (1): 1-25 http://dx.doi.org/10.1016/S0925-5214(02)00246-6

Butler W. L., Norris K. H. 1960. The spectrophotometry of dense light-scattering material. Archives of Biochemistry and Biophysics, 87 (1): 31-40 http://dx.doi.org/10.1016/0003-9861(60)90119-3

Butz P., Hofmann C., Tauscher B. 2005. Recent developments in noninvasive techniques for fresh fruit and vegetable internal quality analysis. Journal of Food Science, 70 (9): 131-141 http://dx.doi.org/10.1111/j.1365-2621.2005.tb08328.x

Chen P., Nattuvetty V. R. 1980. Light transmittance through a region of an intact fruit. Transactions of the American Society of Agricultural Engineers, 23 (2): 519-522

De Ketelaere B., Stulens J., Lammertyn J., Cuong N. V., De Baerdemaeker J. 2006. A methodological approach for the identification and quantification of sources of biological variance in postharvest research. Postharvest Biology and Technology, 39 (1): 1-9 http://dx.doi.org/10.1016/j.postharvbio.2005.09.004

DiNatale C., Zude M., Macagnano A., Herold B., D’Amico A. 2002. Electronic nose and VIS-spectra data fusion for the prediction of fruits characteristics. Proceedings of the $6^{\text {th }}$ Italian conference Sensors and Microsystems - Pisa, Italy, p. $157-161$

Geyer M., Herold B., Zude M., Truppel I. 2007. Non-destructive evaluation of apple fruit maturity on the tree. Vegetable Crops Research Bulletin No. 66: 161-169

Herold B., Truppel I., Zude M., Geyer M. 2005. Spectral measurements on Elstar apples during fruit development on the tree. Biosystems Engineering, 91 (2): 173-182 http://dx.doi.org/10.1016/j.biosystemseng.2005.03.005

Herold B., Kawano S., Sumpf B., Tillmann P., Walsh K. B. 2009. VIS/NIR spectroscopy. Optical monitoring of fresh and processed agricultural crops. Zude M. (ed.). Optical Monitoring of Fresh and Processed Agricultural Crops, p. $141-248$

Hertog L. A. T. M. M. 2002. The impact of biological variation on postharvest population dynamics. Postharvest Biology and Technology, 26 (3): 253-263 http://dx.doi.org/10.1016/S0925-5214(02)00044-3

Kays S. J. 1999. Preharvest factors affecting appearance. Postharvest Biology and Technology, 15 (3): 233-247 http://dx.doi.org/10.1016/S0925-5214(98)00088-X

Knee M. 1972. Anthocyanin, carotenoid, and chlorophyll changes in the peel of Cox's Orange Pippin apples during ripening on and off the tree. Journal of Experimental Botany, 23 (74): 184-196 http://dx.doi.org/10.1093/jxb/23.1.184

Kuckenberg J., Tartachnyk I., Noga G. 2008. Evaluation of fluorescence and remission techniques for monitoring changes in peel chlorophyll and internal fruit characteristics in sunlit and shaded sides of apple fruit during shelf-life. Postharvest Biology and Technology, 48 (2): 231-241 http://dx.doi.org/10.1016/j.postharvbio.2007.10.013

Marquina P., Venturini M. E., Oria R., Negueruela A. I. 2004. Monitoring colour evolution during maturity in Fuji apples. Food Science and Technology International, 10 (5): $315-321$ http://dx.doi.org/10.1177/1082013204047903

McGlone V. A., Hordan R. B., Martinsen P. J. 2002. VIS/NIR estimation at harvest of pre- and post-storage quality indices for Royal Gala apple. Postharvest Biology and Technology, 25 (2): 135-144 http://dx.doi.org/10.1016/S0925-5214(01)00180-6

Mehinagic E., Royer G., Bertrand D., Symoneaux R., Laurens F., Jourjon F. 2003. Relationship between sensory analysis, penetrometry and visible-NIR spectroscopy of apples belonging to different cultivars. Food Quality and Preference, 14 (5): 473-484

http://dx.doi.org/10.1016/S0950-3293(03)00012-0

Merzlyak M. N. 2006. Modeling pigment contributions to spectral reflection of apple fruit. Photochemical and Photobiological Sciences, 5 (8): 748-754 http://dx.doi.org/10.1039/b602160c

Merzlyak M. N., Solovchenko A. E., Chivkunova O. B. 2002. Patterns of pigment changes in apple fruit during adaptation to high sunlight and sunscald development. Plant Physiology and Biochemistry, 40 (6-8): 679-684 http://dx.doi.org/10.1016/S0981-9428(02)01408-0

Merzlyak M. N., Solovchenko A. E., Gitelson A. A. 2003. Reflectance spectral features and non-destructive estimation of chlorophyll, carotenoid and anhocyanin content in apple fruit. Postharvest Biology and Technology, 27 (2): 89-103 http://dx.doi.org/10.1016/S0925-5214(02)00066-2

Merzlyak M. N., Solovchenko A. E., Smagin A. I., Gitelson A. A. 2005. Apple flavonols during fruit adaptation to solar radiation: spectral features and technique for nondestructive assessment. Journal of Plant Physiology, 162 (2): $151-160$ http://dx.doi.org/10.1016/j.jplph.2004.07.002

Peirs A., Lammertyn J., Ooms K., Nicolai B. M. 2001. Prediction of the optimal picking date of different apple cultivars by means of VIS/NIR-spectroscopy. Postharvest Biology and Technology, 21 (2): 189-199 http://dx.doi.org/10.1016/S0925-5214(00)00145-9

Peirs A., Scheerlinck N., Perez A. B., Jóncsok P., Nicolai B. M. 2002. Uncertainty analysis and modelling of the starch index during apple fruit maturation. Postharvest Biology and Technology, 26 (2): 199-207 http://dx.doi.org/10.1016/S0925-5214(02)00038-8

Rutkowski K. P., Michalczuk B., Konopacki P. 2008. Nondestructive determination of Golden Delicious apple quality and harvest maturity. Journal of Fruit and Ornamental Plant Research, 16: 39-52

Rutkowski K. P., Konopacki P., Wawrzynczak A., Michalczuk B. 2009. Estimation of apple ripening stage using optical spectrometry. Environmentally friendly and safe technologies for quality of fruits and vegetables. Algarve, Faro, Portugal, session 1, p. 13

Solovchenko A. E., Chivkunova O. B., Merzlyak M. N., Gudkovsky V. A. 2005. Relationships between chlorophyll and carotenoid pigments during on- and off-tree ripening of apple fruit as revealed non-destructively with reflectance spectroscopy. Postharvest Biology and Technology, 38 (1): 9-17 http://dx.doi.org/10.1016/j.postharvbio.2005.05.004

Solovchenko A. E., Chivkunova O. B., Gitelson A. A., Merzlyak M. N. 2010. Non-destructive estimation pigment content, ripening, quality and damage in apple fruit with spectral reflectance in the visible range. Fresh Produce, 4 (1): 91-102

Solovchenko A., Kozhina L., Nazarov Y., Gudkovsky V. 2011. Relationships between internal ethylene and optical reflectance in ripening Antonovka apples grown under sunlit and shaded conditions. Postharvest Biology and Technology, 59 (2): 206-209 http://dx.doi.org/10.1016/j.postharvbio.2010.08.013

Tijskens L. M. M., Konopacki P. 2003. Biological variance in agricultural products. Theoretical considerations. Acta Horticulturae, 600 (2): 661-669

Tijskens L. M. M., Konopacki P., Simčič M. 2003. Biological variance in agricultural products. Experimental examples. Acta Horticulturae, 600 (2): 671-675

Tijskens L. M. M., Unuk T., Tojnko S., Hribar J., Simčič M. 2009. Biological variation in the colour development of Golden Delicious apples in the orchard. Journal of the Science of Food and Agriculture, 89 (12): 2045-2051 http://dx.doi.org/10.1002/jsfa.3689 
Tijskens L. M. M., Unuk T., Tojnko S., Hribar J., Simčič M. 2011. Colour development in the apple orchard. Journal of Fruit and Ornamental Plant Research, 19 (1): 113-121

Unuk T., Hribar J., Tojnko S., Simčič M., Požrl M., Plestenjak A., Vidrih R. 2008. Effect of nitrogen application and crop load on external and internal fruit quality parameters of apples. Deutsche Lebensmittel-Rundschau, 104 (3): 127-134

Unuk T., Tijskens L. M. M., Germšek B., Zadravec P., Vogrin A., Hribar J., Simčič M., Tojnko S. 2012. Effect of location in the canopy on the colour development of three apple cultivars during growth. Journal of the Science of Food and Agriculture, 92 (12): 2450-2458 http://dx.doi.org/10.1002/jsfa.5651

Watada A. E., Massie D. R., Abbott J. A. 1985. Relationship between sensory evaluations and nondestructive optical measurements of apple qulity. Journal of Food Quality, 7 (3): 219-226 http://dx.doi.org/10.1111/j.1745-4557.1985.tb01053.x

Yeatman J. N., Norris K. H. 1965. Evaluating internal quality of apples with new automatic fruit sorter. Food Technology, 19: $123-125$

Young H., Rossiter K., Wang M., Miller M. 1999. Characterization of Royal Gala apple aroma using electronic nose technology-potential maturity indicator.
Journal of Agricultural and Food Chemistry, 47 (12): 5173-5177 http://dx.doi.org/10.1021/jf990276u

Zude M. 2003. Comparison of indices and multivariate models to non-destructively predict the fruit chlorophyll by means of visible spectrometry in apple fruit. Analytica Chimica Acta, 481 (1): 119-126

http://dx.doi.org/10.1016/S0003-2670(03)00070-9

Zude M., Herold B. 2002. Optimum harvest date determination for apples using spectral analysis. Gartenbaumwissenschaft, 67 (5): 199-204

Zude M., Herold B., Roger J. M., Bellon-Maurel M., Landahl S. 2006. Non-destructive tests on the prediction of apple fruit flesh firmness and soluble solids content on tree and in shelf life. Journal of Food Engineering, 77 (2): 254-260 http://dx.doi.org/10.1016/j.jfoodeng.2005.06.027

Zude M., Birlouez-Aragon I., Paschold P. J., Rutledge D. N. 2007. Non-invasive spectrophotometric sensing of carrot quality from harvest to consumption. Postharvest Biology and Technology, 45 (1): 30-37 http://dx.doi.org/10.1016/j.postharvbio.2007.01.010

Zude-Sasse M., Truppel I., Herold B. 2002. An approach to non-destructive apple fruit chlorophyll determination. Postharvest Biology and Technology, 25 (2): 123-133 http://dx.doi.org/10.1016/S0925-5214(01)00173-9

\title{
Spektrofotometriškai įvertinto pigmentų kiekio sveikuose obuoliuose ir jo ryšio su vaisių kokybe tyrimų apžvalga
}

\author{
N. Sadar, A. Urbanek-Krajnc, T. Unuk \\ Maribor universitetas
}

\section{Santrauka}

Jau keletą pastarujų dešimtmečių vartotojų lūkesčiai dẻl obuolių kokybės nuosekliai didèja. Viena svarbiausių kokybès savybių, lemianti kainą, yra obuolių spalva. Ją labiausiai lemia santykinis pigmentų chlorofilų, karotenoidų ir antocianinų kiekis, kurį nepažeidžiant obuolio galima pamatuoti naudojant spektro matomosios dalies spektrofotometriją.

Straipsnyje pateikta trumpa apžvalga tyrimų, susijusių su optiniu pigmentų nustatymu sveikuose obuoliuose, naudojant elektromagnetinio spektro matomają dalį. Apžvelgiami pigmentų pokyčiai, susiję su obuolių nokimu, ir aiškinami šviesos sąveikos su medžiaga pagrindai, matavimus atliekant neskaidrioje medžiagoje. Aptariami du tinkamiausi pigmentų nustatymo sveikuose obuoliuose būdai ir pateikiama pavyzdžių. Pateikiama diskusija apie ịvairius atspindžio ir perdavos rodiklius, naudojamus pagrindinių pigmentų kiekiui bei kokybei nustatyti. Rezultatų skyrelyje pateiktos priklausomybės tarp spektro duomenų bei gautų rodiklių ir ịvairių kokybès bei nokimo rodiklių. Išvadose pristatyti ir trumpai aptarti svarbiausi tyrimų rezultatai.

Reikšminiai žodžiai: antocianinai, branda, chlorofilas, kokybė, obuoliai, spalva, spektro matomosios dalies spektrofotometrija. 